\title{
THE EVOLUTION AND CLASSIFICATION OF THE CEPHALOPODA, AN ACCOUNT OF RECENT ADVANCES.
}

\author{
By Prof. J. F. BLAKE, F.G.S. \\ Being the Presidential Address delivered February 5 th, 1892.
}

T $\mathrm{T}$ has always been a marvel that the species of Orthoceras and Ammonites were so long allowed to accumulate without any attempt being made to split up the forms included under these names into more restricted genera. Up to the year 1865 , however, no such genera were established for any of the ordinary forms, the only separation being for such as showed some special peculiarity, e.g., Endoceras, Gonioceras, Turrilites, and Hamites : it was as though no one dared to commence the operation; and Palæontologists were content with the divisions into groups. In that year Prof. E. Suess, of Vienna, wrote a paper "Ueber Ammoniten," * in which he drew attention to the varying lengths of the body-chamber in Ammonites, and to the special forms of aperture which some of them presented; and on these characters he founded the Triassic genus Artestes and the two Liassic genera Phylloceras and Lyloceras. Even then Palæontologists seemed averse to enter on the road thus opened before them, and Prof. Zittel of Munich was the first to make use of these generic names in a publication three years later.

In 1867 , however, an entirely independent commencement was made by Alpheus Hyatt of Cambridge, Massachussetts, in a paper entitled "The Fossil Cephalopoda of the Museum of Comparative Zoölogy." + The subdivision therein attempted was on a much more extensive scale, though it was entirely confined to the Ammonites of the Lias. He stated that Prof. L. Agassiz had long considered the groups of Von Buch to be natural families "capable of division into subordinate groups of generic importance." He further stated that he had pursued no special method in the classification; which is an important admission in the light of later developments. Under this scheme he recognised the following families:- Psiloceratidæ, Discoceratidæ, Liparoceratidæ, Deroceratidæ, Thysanoidæ, Dactyloidæ, Phymatoidæ, Amaltheidæ, Cycloceratidæ, and Hildoceratidæ. Many of these ten families have since been altered by their author, though the generic names that he still retains date from this publication. It may be certainly said that this classification fell, in Europe at least, entirely flat. The families and genera were

* Sitzungsb. d. Wiener Akad., vol. lii, p. 71 : 1865.

† Bull. Mus. Comp. Zöl. Harvard, vol, i, No. 5, pp. 71-102 : ^867.

APRIL, I 892.$]$ 
considered to be ill defined, and to contain a heterogeneous mixture of species; while the author himself scarcely knew, perhaps, whither his researches were leading him.

In $\mathrm{x} 869$ an entirely new method of considering the relations of one species of Ammonite to another was inaugurated by Dr. Waagen, in a paper entitled "Die Formenreihe des Ammonites subradiatus." "In this research he placed before him all the Ammonite species that were nearly allied to $A$. subradiatus, and, assuming the theory of descent, which Darwin had only promulgated nine years before, he asked the question which was the probable inmediate ancestor of any particular form. The whole of the series thus considered was traced back by him to two forms of the oldest subradiatus type, viz., $A$. subradiatus itself and $A$. grenicularis. These two he called the root forms, and represented all the others by what he called a "genetic formula," thus, A. $\frac{\text { fuscus }}{\text { subradiatus }}$ or $A$. $\frac{\text { subfuscus }}{\text { genicularis. }}$ But, what was still more important, he drew out a table of descent. Taking the species in any particular zone of the Lower and Middle Oolites, he traced out what was the probable immediate ancestor of each in the zone below, and the immediate successor in the zone above; he then connected these by vertical lines into a number of series which converged at the base to the original $A$. subradiatus in the lowest zones. These series were his true "Formenreihe," a word which he translated, six years later, in his Jurassic Fauna of Kutch, $\uparrow$ by the phrase "developmental series."

The principle which lies at the base of this method is seen on consideration to be one of enormously wide-reaching import. The relation of one of the forms in this developmental series to those which precede and follow it is entirely distinct from the relation of one contemporaneous species to another. In the former it is a direct genetic relation; in the latter it is a relation of similarity, which may or may not be due to a more remote genetic relationship. Now the words "genus" and "species" connote the similarity of structure, more or less complete, of contemporaneous forms; consequently, when we are dealing with a genetic series these terms are inapplicable, and if this system of study be pursued the whole scheme of Linnean nomenclature may be brought to an end. We must remember that it was the opinion, both of Linnæus and of the vast majority of those under whose care the present binomial nomenclature has been built up, that there were just so many species in the world as God at first created, and no more. The system which is built on such a view is naturally ill fitted to express the ideas of the other and somewhat contradictory view of descent with modification. In the case of contemporaneous species, the main object is to discrimi-

* Ceogn, Palaeont. Beiträge, Bd. it., Heft ii.

+ Palreontologia Indica ; Mem. Geol, Strvey E, India : $187 \mathrm{r}$. 
nate one from the other; bat with successive forms in a genetic series we chiefly desire to learn their relations to each other. Hence these latter cannot be so sharply marked off, while points in their structure, which are slighted from the "specific" point of view, are to be carefully dwelt on. Dr. Waagen expresses himself as follows on this point (Jurassic Fauna of Kutch):-- "Happy is he who is able to distinguish the very finest differences of form which organisms undergo in their development in time. This cannot be done without pointing out, with the utmost carefulness and exactitude, certain stages which are conspicuous in one way or the other, and these latter form the Palæontological species, a thing very different from the species of Zoologists, and equally different from the varieties of the same." He goes on to say that if the name species be objected to for these forms, which it surely may very well be, such forms may be called "mutations." It is in this way, he says, that Palæontology asserts itself as a science of its own.

Another writer, L. Würtenberger, who entered early on this kind of research, expressed himself on this point, at a later date, I 880 , still more clearly.* "The species," he said, "which are living to-day are the final points of the twigs of the great genetic tree, and thus are more or less separate from each other; but in dea!ing with fossils we have to do with a single twig which has undergone changes in itself, of which our view is only unbroken in proportion as the series of beds in which they are contained is complete. From this point of view species have no basis of existence. They are an idea derived from researches in the living world, and become more and more unnatural as our knowledge of development increases. The species spoken of in Palæontology are only the resting-places for men's understanding in looking over the series of forms, and have no further foundation in Nature. If we compare the fossils of any single epoch of the past, they appear as distinct as those of to-day, because we take, as it were, a section across the twigs and branches of the great genetic tree."

The objection to call by the name of species what Waagen calls mutations is obviously felt by modern German writers, such as Wähner and Bukowski, who, when assigning a new name, speak of a "new form" only. But, if the individual forms are not really "species," much less can the developmental series be called a "genus"; for in that case every living species must also constitute a genus. We might, perhaps, call it a "lineage," or some such name; but, in any case, the distinct idea must require distinct nomenclature. This has certainly not been very clearly kept before the eyes of recent writers; consequently the same kind of name sometimes denotes a genus and sometimes a lineage. Thus some of the names of Hyatt are distinctly those

* Studien ueber die Stammes-geschichte der Ammoniten. Ein geologischer Beweis für die Darwin'sche Theorie. \&vo. Leipzig, 1830. 
of lineages, e.g., Arnioceras; yet the same writer uses the name Dimorphoceras for two peculiar Goniatites which are strictly contemporaneous. This difficulty may, perhaps, be got over by considering a genus to include all the lineages which lead up to the several species of the Zoological genus.

Perhaps the point which I have been here insisting on may be made clearer by a geometrical illustration. Let any single epoch be represented by a horizontal line, and let the several species of a group of organisms be arranged along that line, in greater or less proximity according to their structural similarity ; then the bracket which unites all these into a single genus will be a horizontal one. When, however, we consider a previous epoch, it will be represented by another horizontal line vertically below the first ; then any bracket which unites any species of this epoch with a species of the succeeding epoch will be more or less vertical. However closely, then, the several species approximate horizontally, they can never be on the same vertical. Thus any single form may be a species to its contemporaries, and form a gerus with its borizontal neighbours; but it is at the same time a mutation to its predecessors, and forms a lineage with them.

I have dwelt particularly upon this, because it seems to me that, as Waagen says, we have here the true basis of Palæontology as an independent science ; and it is the study of the Cephalopoda which has been chiefly instrumental in laying the foundation-stone. Zoologists, as such, have been very forward in promulgating theories of descent; but, to use mathematical language, their studies have reference to the abscissæ, while Palæontology alone can deal with the ordinates.

The path thus opened by Waagen has been largely followed by other writers, such as Neumayr, Mojsisovics and Haug, and quite independently by Hyatt. But of the so-called "generic" names in use, some represent a zoological genus, some a lineage, and some, as those of Waagen himself, the several lineages which may arise from one root-form, and thus terminate in a zoological genus.

When, in 1876 , I had the pleasure of introducing, in "The Yorkshire Lias," the new nomenclature for Ammonites to English literature, my genera were used in Waagen's sense, though without any clear idea, as I must confess, of their distinctness from zoological genera; and so far from attempting to group them in lineages, I said that they were "certainly not modified or developed from others previously existing on the spot," the idea being that they had migrated to Yorkshire from the place of their origin. We now, however, know the Liassic and Triassic faunas from so many localities, and the succession in each is so similar, that we can no longer appeal from one locality to another, but must fairly face the fact that, if any species has been developed at all from another, it must, in most cases, have been from one or 
other of the forms which are actually lying before us. If this be the case, however, we must give up the idea of the extreme slowness of the process of development, which the theory of Natural Selection has led us to entertain, and adopt instead the views of Prof. Hyatt thus expressed in 1883:- * "Our impression derived from the minuter study of series among Cephalopoda is not that the evolution of groups was slow, but on the contrary excessively rapid, and that the groups, if presented graphically, would form fan-shaped figures instead of long branches." "Types near their point of origin are more plastic, and more easily changed by the forces acting upon their generalised structures."

The problem thus set before us of connecting by supposed genetic affinity the different forms in our collections is a very inviting one, and leads undoubtedly to the closer study of the various peculiarities of the forms; yet it is an extremely difficult one, and we can only hope to solve it after a long preliminary study of general principles, and the accumulation of a vast quantity of material. Nothing, of course, is easier than to seize upon some of the many resemblances which each form presents to those around it, and, giving these features an importance they have never been proved to possess, to lay down the supposed genetic affinities, and so to build up any number of fictitious genealogical trees. These attempts are not, however, unmitigated evils, for they serve to draw attention to certain resemblances which may, in the end, prove to be in some way connected with the genealogy.

There are two kinds of preparation necessary for the successful attack of this problem, even when we have all the necessary data before us. The first is the careful observance, both of the changes which the various parts of the organism undergo throughout the entire course of the life of the individual, and of the probable general evolution of the group. The second is the induction from these particular cases of some general laws of development, which shall enable us to deduce the genealogy in other particular cases. This, of course, is merely to state the method of inductive science; but, though the method is always supposed to be followed, it is only by keeping it carefully in view that we can make sure progress.

The basis of the primary induction with regard to the development of Arnmonites had been already long accumulated in the works of D'Orbigny and others before these newer studies commenced; consequently, the first step taken was an induction of general principles by Hyatt, in I866.t This paper even antedated Waagen's, but it had no direct bearing on classification.

* "Fossil Cephalopoda in the Museum of Comparative Zoology." Proc. Amer. Assoc. Adv. Sci., vol. xxxii, p. $3^{2} 3$, Minneapolis, 1883 .

t "On the parallelism between the different stages of Life in the Individual, and those in the entire Group of the Molluscous order, Tetrabranchiata." Mem. Boston Soc. Nat. Hist., vol. i, part ii, p. 193,1867 . 
He drew attention to the five stages in the life of an Ammonite as described by D'Orbigny, and, comparing these with successive forms amongst allied species, arrived at the conclusion with respect to this group to which Darwin had previously arrived for animals in general, that the individual history or ontogeny was an epitome of the racial history or phylogeny. He also laid down a now well-known biological law, which he spoke of as the acceleration of development. Darwin had said that, under the law of heredity, offspring tended to reproduce the characters of their parents at the same stage of life as that at which they had at first appeared though sometimes earlier. This is generally true when a long succession is not considered; but Hyatt modified it by saying: "The young of higher species are constantly accelerating their development, and reducing to a more and more embryonic condition, or passing entirely over, the stages of growth corresponding to the adult periods of preceding or lower species." He also recognised that this might be carried so far that the old age characteristics might in time become embryonic, and thus affect the entire growth. In illustration of these laws, he quoted the series Ammonites hybrida, A. Henleyi, and $A$. Bechei from the Lias, thus approaching very near to a classification by lineage in which he has since become so forward a worker.

Now it can be shown that these laws are a priori deducible from the theory of descent. If any particular animal be derived from a previous, differing animal, it must reproduce all the parts of the latter except those in which it differs. Consequently either itself or its ancestors must represent in themselves all the previous stages which have led up to the latest form. If all are found in the individual itself, then we have the law of the ontological epitome of the phylogeny. Moreover, as more stages are passed through in the same period by the later forms, this involves a law of acceleration. If they are not all found in the individual, it must be the earlier ones that are lost, since the lost ones must have been possessed by ancestors which never acquired the later modifications; and this gives us the law of acceleration by curtailment. The fact, therefore, that we observe these laws to be actually true in nature is a proof of the truth of the theory of descent. If we accept that theory these laws must necessarily be our guide in searching for genetic relationships.

These principles are applied to Ammonites as follows : if we want to know the nearest ancestor of a form $A$, we must find a form $B$ which reproduces in the adult the early whorls of $A$; in the same way $C$, the immediate ancestor of $B$, must reproduce its early whorls : and so the series grows. It may, however, often happen, on account of the acceleration, or even abbreviation by curtailment, of development, that the early whorls of the latest A do not show us the stages so far back in the history, even on a diminished scale, as the early, or even the later, whorls of $C$; 
and so it might be proved, step by step, that a form which, neither in its adult stages nor in any earlier stage agreed with a second, might. yet be of the same lineage. In this way a well proved lineage may pass from so-called species to species, from so-called genus to genus, and from so-called family to family. As these ideas were in the mind of Hyatt in 1866 , his genera in 1867 were doubtless founded upon them ; but as he did not explain the matter it was no wonder that they seemed a heterogeneous mixture.

I have quoted above, for the sake of completeness, some remarks which were made in 1875,1876 , and 1880 ; but must now take up the story from 187 . In that year M. Neumayr published part iii of his "Jura Studien,"* in which he developed Waagen's plan of working out several "Formenreihe" or developmental series amongst the forms of Phylloceras. He recognised that the last of a series might become simple by degeneration or atavism, as well as the fact that the relation of one form to another in the series was quite distinct from the relation of one contemporary species to another, but considered the forms as comparable to varieties, from which, however, as noticed later by Würtenberger, they are equally distinct. The recognition of the relation between these forms seems to have been made entirely by a comparison of adult forms, combined with their known succession in time. Neumayr gave no figures of the young, and he was certainly unacquainted with the law of acceleration of development, since he concurred at a later date in its ascription to Würtenberger, by whom it was not published till two years later. Even Waagen's own "Formenreihe" were wanting in this basis of proof, and all we can say either of his or Neumayr's is that they may or may not be found correct when the proofs are forthcoming.

The researches of Würtenberger on this subject were published in 1873 in a pamphlet called "Ausland." Herein he made known two laws of development. The first was that of "adaptation in adult life"; that is, that the period in which new departures were to be best observed was when the animal was in full vigour. The second was that of "earlier inheritance," which was identical with that of "acceleration of development." This latter law has therefore been ascribed to him by those unacquainted with Hyatt's earlier writings. Undoubtedly he worked it out independently, as he seems to have been unaware even of the existence of Hyatt.

The latter author, however, was making steady progress, and publishing his results in the Proceedings of the Boston Society of Natural History. In a paper "On Reversions among the Ammonites," + in 1870 , he traced several developmental series from the root-stock of what he called Microderoceras Birchii. In a paper

\footnotetext{
* K. K. Geol. Reichsanst, Wien. 1874 .

+ Proc. Boston Soc. Nat. Hist., vol. xiv, pp. 22-43, and Appendix in vol. xvii, pp. 23-27;
} 
on "Genetic Relations of the Angulatidæ," in I 874, he traced a series from Agoceras incultum of the Trias to $\mathscr{E}$. Boucaultianum of the Lower Lias; and in an appendixt to a paper on "The nonreversionary series of the Liparoceratidx, " + he traced several diverging series from Deroceras Dudressieri of the Lower Lias up to three branches in the Upper Lias and two which terminated in the Middle Lias, in this case calling each lineage by a distinct "generic" name. In 1876 he published the "Genetic relations of Stephanoceras," $\$$ in which he gave an account of the genetic development of $S$. nodosum of the $A$. Humphresianus zone into eight branches, one of which reached to the "athleta-bed"; but he called them all by the single name Stephanoceras, thus using the generic title in Waagen's sense. In this paper he also makes several important general remarks, amongst which he says that adult forms of different lineages may sometimes closely resemble each other, but are then to be distinguished by the differences in their earlier whorls, which prove them to have arrived at their final stages by different routes. He introduces the term geratology for the study of the senile characters of an individual or series, and says that the final terms of the series present in adult life the geratologous characters of the earlier forms, so that these characters, though unfavourable to the animal, are also accelerated. $\mathrm{He}$ adds that in these the adult characters may be skipped and old age ones succeed the young at once, and that this leads to an extinction of types. This last assertion may be true, but it is difficult to see how it can be proved, as in this case the clue is lost which should guide us to the route by which the senile characters have been reached. Moreover, though included in Hyatt's statement of the law of acceleration, it has no $a$ priori foundation and is not a necessary part of that law.

All these papers of Hyatt's are rather brief, and, though one may have every confidence in the correctness of his results, the proofs are not given in sufficient detail to carry conviction in themselves, or even to clearly illustrate the method pursued.

It is different with Würtenberger's paper called "Studien über die Stammesgeschichte der Ammoniten." A Although he started off with the extraordinary statement that no one except Neumayr had attempted to trace the derivation of Ammonites, he gave a full and very instructive account of the changes traceable in certain selected groups, thus enabling one for the first time to realise the powers of this method. One of these groups started with the Planulati of the Lias, such as Ammonites communis and A. annulatus, and from them he traced seven stages of change :-

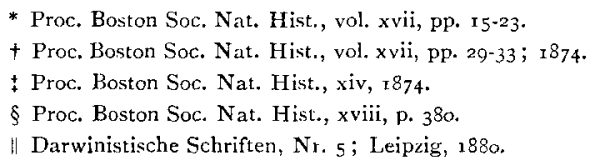


Ist. The biplication of the ribbing over the ventral surface became more complex, so that there might be four ribs to one.

$2 n d$. The bifurcation of the ribs began nearer the umbilicus.

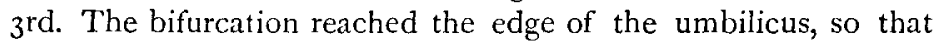
the secondary ribs became primary.

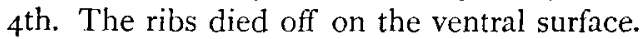

5 th. Spines or knobs might be developed at the points where there was a change in the ribbing, i.e., at the junctions of the primary and secondary ribs, of the primary ribs and the umbilicus, and of the ribs and outer forks, the outermost row of spines being always developed first.

6 th. The ribbing might die off.

7 th. The spines died off by degrees, first the outer row and then the inner, leaving at last a perfectly smooth shell.

In each case in particular species two adjacent terms of this series might be seen on the same specimen, the earlier stage always on the inner whorls. In the example of $A$. athleta, figured by Quenstedt in his "Jura," Plate $7 \mathrm{I}$, fig. I, the ribbed, the onespined, and the two-spined stages may be seen on a single specimen. The sequence here traced out, providing it be a true one, forms but a single lineage, which commences in the genus Colnceras, and passes by Peltoceras to Aspidoceras. Yet Würtenberger used no generic title at all beyond Ammonites, showing how entirely distinct are the two methods of studying these fossils at present in the field. There are, of course, several branches to this development, and each of them will form a separate lineage. If such lineages be objected to as heterogeneous, it can only be replied, as Würtenberger did, that if you take a single specimen of certain forms, the outer whorls alone would be referred to one genus, and the inner whorls alone would be referred to another.

By about this time Hyatt's writings appear to have become better known in Europe, and under the influence of these and the other works above mentioned, palæeontologists, as, for instance, Haug and Wähner, have since that date generally endeavoured to draw up a genealogical scheme of succession for the group they have been describing, following more or less closely the principles above laid down. How far these attempts have been successful can hardly yet be judged. Doubtless they are destined to undergo much. modification. As Haug remarks in the "Annuaire Géologique" for 1888, there are two methods of studying the evolution of a group: one is the original method of Waagen, who takes all the species of a given section of Ammonites, independently of age and locality, and seeks the relation between their affinities and their range in time; the other is to describe all the species coming from the same bed and same region, and to seek to establish the relations between these and the preceding and succeeding faunas as a whole, after the manner of Neumayr, 
Gemellaro, Fontannes, Uhlig and Pavlov. The latter is the slowest but surest way.

In our own country but little progress has been made. Dr. Wright noticed the changes that passed over certain Ammonites in their progress from youth to age, but made no attempt to apply it to the genealogy of the forms described; and the only disciple of the new school, dealing with detailed faunas, has been S. S. Buckman. In his remarks on the evolution of the Hildoceratidæ, in the Palæontographical Society's volume for 1888 , he showed that he had got hold of the true laws governing the development of successive forms, curiously enough, as he confessed a year later, without having read any of Hyatt's writings on the subject, and apparently in ignorance of Würtenberger. This independent discovery of these laws by three different workers is a strong proof of their truth. In his paper "On the Descent of Sonninia and Hammatoceras," "* Buckman showed these laws in action, and whether his results be ultimately found correct or not, the true method of discovery undoubtedly was pursued. The greatest care, however, and the fullest attainable knowledge are required to lead to correct results; and these will be best obtained after an exposition of the whole fauna of the epoch chosen.

The climax of this line of research at present, has been recently, reached in the magnificent memoir of Hyatt, published apparently in 1890 , on the "Genesis of the Arietidx." $\uparrow$ In the introductory portion of this monograph he advances new principles, which must be carefully considered. The first of these is his doctrine of "morphological equivalence," which he lays down as follows: "In the different genetic series of a type derived from one ancestral stock there is a perpetual recurrence of similar forms in similar succession, which are usually called representative and falsely classified together, though they really belong to divergent, genetic series." To explain this we must first introduce the terms he makes use of, which he has adopted from Haeckel. In tracing the succession of forms in a series we find them but illcharacterised at first, then gradually putting on the special pecuJiarities of their highest development, and lastly losing these again. These three stages are called the "epacme," the "acme," and the "paracme" of the group. As the series passes up from the epacme to the acme it is progressive; as it passes down again to the paracme it is retrogressive. The corresponding terms in the development of the individual, after it has passed the embryonic stage, are called the "nepionic," representing the earliest youth, the " nealogic," representing adolescence, the "ephebolic," representing the adult, and "geratologic," representing the period of old age, which latter he subdivides into a "clinologic" stage, in

\footnotetext{
* Quart. Journ. Geol. Soc., vol, xlv, pp. 65I-663, Pl. xxii, Nov., r889.

$\dagger$ Snithsonian Contributions to Knowledge, 673, Washington, 1880 .
} 
which the ephebolic and nealogic characters are lost, and a "nostologic" stage, in which the organism goes back to its nepionic characters. And he states the relation of these terms to each other thus: "The anaplastic relations of the nepionic and nealogic stages to the phenomena occurring during the epacme of groups, the metaplastic relations of the ephebolic stage to the phenomena occurring during the acme of groups, and the cataplastic relations of the geratologic stages to the phenomena occurring during the paracme of groups, are the functional relations of the structural modifications occurring in the ontogeny of individuals to those which are characteristic of the phylogeny of groups."

Now, applying the doctrine of morphological equivalence to the outward form of the shell, he says that in any given series the forms will be first arcuate, then coiled, then close-coiled or discoidal, and finally involute: thus far the forms are progressive, and they will reverse this order when they become retrogressive. Thus, in the Palæozoic periods, we reach in succession the Orthoceratic, the Cyrtoceratic, the Gyroceratic, and the closecoiled Nautiloid stages. In the Jurassic period acceleration of development has obliterated these early stages, and we commence at once with the discoidal forms. These progressively become more involute up to their acme, and then uncoil again to produce the retrogressive types "Ancyloceras," "Crioceras," and finally the straight "Baculites." The rapidly developing Ammonoids, whose Goniatite stage was the contemporary of Orthoceras, died out with the Cretaceous period; but the more slowly developing Nautiloids have not yet entered on their geratologic stages.

Applying the same doctrine to the sutures, Hyatt notes how they become more complex during the progressive stages, and return to their early simplicity during the retrogressive stages, Hamites and Baculites having simple sutures, though this class of character never puts on such a nostologic type as does the general form of the shell. The same law may also be applied to the development and loss of ornaments.

On all this he remarks, that to class together forms as genera because they are straight, or curved, or discojd, as in the case of Orthoceras, Cyrtoceras, Nautilus, Ammonites, and Baculites: or because their sutures are angular or complex, as in the case of Goniatites and Ammonites; or because they are keeled or rounded on the front, as Egoceras and Arietites, is to confound morphological equivalents with true genetic series; and thus he would sweep away all the old generic terms.

It seems to me that all this is, for the most part, only putting into formal language that which has already been deduced from the previous writings of both Hyatt and others; namely, the distinction between the genus of contemporaneous species and the lineage of successive forms. Unfortunately, Hyatt still uses the 
word genus, at a great risk of confusion, for a single genetic line. 'Thus he says :-_ "The unit of classification is, therefore, not the species, but the genus; in other words, it is the smallest natural group which is genetically connected, and in which a more or less complete cycle of forms or species may be traced. In such a system, also, certain radical forms which do not show the usual morphogenetic cycle may occur. . . . These may have a closcly allied and inseparable series of varieties, which cannot be distributed into the different genera arising from them. In such cases, the radical may be considered as an undeveloped series, and separated as a distinct genus, though it consist of but one species with well marked varieties." All we want to alter in this is to substitute "lineage" or some equivalent word for "genus," and "form" or "mutation" for "species."

There are, however, cases in which the term morphological equivalent has a special value. Thus in the Cretaceous rocks there is an Ammonite closely resembling $A$. oxynotus, which is called by its describer Oxy'noticeras. Now Oxynoticeras, according to Hyatt, is a geratologous form of Arietidce. But since there are no Arietida occurring in the Cretaceous from which it could have degenerated, the Cretaceous form cannot possibly be of the same lineage. It must be a geratologous form of some other lineage, and only a morphological equivalent of Oxynoticeras.

The true characters that are common to the members of a single genetic series Hyatt calls morphological differentials, and states that they arise transiently at first, then become general, and die out in retrogressive steps.

He next distinguishes between progressive and retrogressive series, and states that they always start from corresponding types. Thus every progressive type amongst Jurassic or Cretaceous Ammonites must start from a discoidal or evolute ancestor, and be monophyletic in origin. Retrogressive types, on the other hand, must start from involute types, and may be polyphyletic in origin. The last statement can only mean that the morphological equivalents in nostologic types are so difficult to distinguish that they are generally classed together.

The original radicals in Palæozoic times from which all of the Ammonites have taken their origin Hyatt calls the primary radicals: such are Bactrites, Mimoceras (a Goniatite evolute in youth), and Anarcestes (a form of Goniatite). 'Those of the Trias are secondary radicals, and he considers them to include Gymnites and Arcestes. 'The earliest form in the Lias is a Tertiary radical, called by him Psiloceras (i.e, Ammonites planorbis). There is thus a continuity in descent of the discoidal shells, and a primitive trunk line of generalised radicals from the earliest times to the Jura.

Finally, Hyatt discusses the cause of the development of these series, and concludes that a theory of evolution should emphati- 
cally deny that heredity tends to produce like with variations, or that there is any such thing as a tendency to variation which is inherent, and not produced by external forces. His view, however, is that an animal cannot be directly changed by external circumstances, but by its own efforts in response to the requirements of its surroundings; in other words, he is a NeoLamarckian. We may or may not agree with him in this view, which is not specially founded on Palæontological results; but there seem to be better grounds for the statement that a struggle for existence either produces no new forms, or at best only retrogressive series; while progressive series arise when types near their point of origin are exposed to new and favourable conditions under which they can freely develop.

Leaving, however, these theoretical points, there can be no doubt that the inductions laid before us by this author are pregnant and wide-reaching, though they leave, perhaps, too large a margin for the interpretation of almost any conceivable series of phenomena.

It will be noticed that the questions already dwelt with concern chiefly the minor groupings of the forms, and their solution has depended almost entirely on observations of external form and ornaments, and to a slight extent only upon the sutures of the adult.

The larger questions of the general classification of the whole class of the Cephalopoda have depended on an entirely different series of observations, in which, also, progress has been considerable. These observations have been made on the less obvious features, such as the form of the earliest chambers, the shape of the first and later septa, and the form and position of the siphuncle.

We may regard it as an ancient observation, finally confirmed by Barrande between $\mathbf{I} 867 \cdot 70$, that whereas the first chamber of Ammonites and Goniatites is globular and joins the succeeding chambers by a constricted neck, that of the Nautiloids is conical and passes to the next without constriction. Now, when it is remembered that the protoconch of Belemnites is globular, and that, of the two septated shells belonging to living animals, the one with a globular protoconch, Spirula, is dibranchiate, and the one with a conical protoconch, Nautilus, is tetrabranchiate, there can be no question that the evidence of this part of the shell by itself is in favour of the dibranchiate character of the Ammonoidea. On the summit of the conical first chamber of Nautiloids is often seen a round or oval depression, called the cicatrix. The meaning of this was for the first time discussed by Hyatt, in 1872 , in a paper entitled "Fossil Cephalopoda of the Museum of Comparative Zoölogy, Embryology," * and it still occupies his attention in his most recent publication in 1890 .

* Bull. Mlus. Comp. Zö̈l, Harvard, vol. iii, No. 5, pp. 59-108. Cambridge, Mass., r872, 
According to his view, this depression marks an aperture through which the embryo passed into the first visible chamber, which is thus a deuteroconch. The difficulty of understanding how a passage could be afforded by so small an opening, which seemed insuperable to Barrande in 1877 , was explained by Owen, in 1878 , as due to its having been narrowed by shell deposit after the passage of the animal. It is certain that shell deposition does take place at the surface of the initial spire, for Hyatt figures the concentric lines produced by it in Nautilus, and Barrande points out the fact, which he cannot, he says, account for, that thirty-two out of thirty-seven examples which show the cicatrix are specially ornamented around it. Barrande's view is that some plug or byssus passed through it, and, undoubtedly, the swollen edge indicates rather a positive structure than an aperture. In 1882 , however, I showed* that in the recent Nautilus there was no proof that any aperture ever existed in the position of the cicatrix, since the layers of shell beneath it were perfectly continuous, and it was, therefore, probably only due to irregularity of surface deposit. Barrande, also, in 1877 , gave details of forty-eight initial chambers, in not one of which could any sign of an earlier chamber be detected,'and eleven of which were without a cicatrix. Notwithstanding all this, Prof. Hyatt, in his recent publication, still adheres to the opinion that there was an earlier chamber in Nautiloids than that generally seen, and he figures two specimens in the British Museum which are supposed to show it, but which, to me, are not convincing. 'The difficulty arising from the fact that the actual first chamber both of Nautilus and Ammonites contains the commencement of the siphuncle, he gets over by assuming an acceleration of development in the latter, by which its siphuncle is developed in the first instead of in the second chamber. Truly this law of acceleration is a two-edged sword, for, according to Munier-Chalmas, there are structures in the first chamber of Ammonites which Hyatt compares to the siphuncle in Endoceras: so that it may represent, according to such an explanation, many chambers in Nautilus, up, in fact, to the point where the shell has gained as much involution as in the Ammonite; and yet the only isolated first chamber is to be found in the Nautilus. We cannot wonder then at, what Hyatt calls, "the uncompromising attitude of those who insist upon the naked facts and are hostile to explanations." He asks them to show the cicatrix in an Ammonite; but this is by no means necessary, if it be of no functional importance, and in any case it is absent in eleven out of forty-eight Nautiloids.

A new departure was made by Branco in his "Beiträge zur Entwickelungsgeschichte der fossilen Cephalopoden." $\dagger \mathrm{He}$

\footnotetext{
* British Fossil Cephalopoda, Part I. $4^{\text {to. London. }}$

† Palæontographica, vol, xxvi, No. $14 ; 1879$, and vol. xxvii, No. $12 ; 1880$.
} 
Table I.-HYATT'S Classification of Cephalopoda, $188_{3}$.

\begin{tabular}{|c|c|c|}
\hline \multicolumn{2}{|c|}{ TETRABRANCHIATA. } & \multirow{18}{*}{$\begin{array}{l}\text { DIBRANCHIATA. } \\
\text { BELEMNOIDEA } \\
\text { SEPrOIDEA. }\end{array}$} \\
\hline NAUTILOIDEA. & AMMONOIDEA. & \\
\hline $\begin{array}{l}\text { Holochoanoida } \\
\text { Prochoanites }\end{array}$ & $\begin{array}{l}\text { Goniatitinae } \\
\text { Nautilinidaae }\end{array}$ & \\
\hline $\begin{array}{l}\text { Metachoanites } \\
\text { Thionotido }\end{array}$ & Chlorochoanites & \\
\hline $\begin{array}{l}\text { Tainoceratadiae } \\
\text { Ellipochoanites }\end{array}$ & $\begin{array}{l}\text { Primordiales } \\
\text { Magnosellaridae }\end{array}$ & \\
\hline Actinoceratidae & Glyphioceratidae & \\
\hline $\begin{array}{l}\text { Orthoceratidae } \\
\text { Gomphocertidge }\end{array}$ & 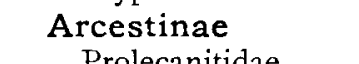 & \\
\hline $\begin{array}{l}\text { Gompnoceratcliae } \\
\text { Mesoceratidae }\end{array}$ & $\begin{array}{l}\text { Prolecanitidae } \\
\text { Clymeninae }\end{array}$ & \\
\hline $\begin{array}{l}\text { Ascoceratidae } \\
\text { Maelonoceratidae }\end{array}$ & Cyrtoclymenidae & \\
\hline $\begin{array}{l}\text { Madonoceraldae } \\
\text { Oncoceratidae }\end{array}$ & $\begin{array}{l}\text { Cymacclymenidae } \\
\text { Gonioclymenidae }\end{array}$ & \\
\hline $\begin{array}{l}\text { Hercoceratidae } \\
\text { Rutorartidae }\end{array}$ & Ceratitinae & \\
\hline Eudoceratidae & $\begin{array}{l}\text { Lytoceratinae } \\
\text { Thysanoideae }\end{array}$ & \\
\hline Gonioceratidae & $\begin{array}{l}\text { Thysanoideae } \\
\text { Ammonitinae }\end{array}$ & \\
\hline $\begin{array}{l}\text { Apsidoceratidae } \\
\text { Trigonoceratidae }\end{array}$ & $\begin{array}{l}\text { Ammmonitinae } \\
\text { Psiloceratidae }\end{array}$ & \\
\hline Triboloceratidae & $\begin{array}{l}\text { Arietidae } \\
\text { Liparoceratidae }\end{array}$ & \\
\hline $\begin{array}{l}\text { Appoceratidae } \\
\text { Nautilidae }\end{array}$ & $\begin{array}{l}\text { Deroceratidae } \\
\text { Der }\end{array}$ & \\
\hline Macrochoanites & $\begin{array}{l}\text { Dactyloidae } \\
\text { Phymatoidae }\end{array}$ & \\
\hline & $\begin{array}{l}\text { Hildoceratidae } \\
\text { Stephanoceratidae } \\
\text { \&c., \&sc. }\end{array}$ & \\
\hline
\end{tabular}

Table II-FISCHER'S Classification of Cephalopoda, I882-3.

\begin{tabular}{|c|c|c|}
\hline $\begin{array}{c}\text { TeTRABRANCHiata. } \\
\text { Prosiphonata } \\
\text { Nothoceratidae } \\
\text { Retrosiphonata } \\
\text { Nautilidae } \\
\text { Ascoceratidae }\end{array}$ & $\begin{array}{l}\text { AMмоNEA. } \\
\text { Goniatitidae } \\
\text { Arcestidae } \\
\text { Tropitidae } \\
\text { Ceratitidae } \\
\text { Clydonitidae } \\
\text { Pinacoceratidae } \\
\text { Amaltheidae } \\
\text { Ammonitidae } \\
\text { Lytoceratidae } \\
\text { Haploceratidae } \\
\text { Stephanoceratidae }\end{array}$ & $\begin{array}{l}\text { DibRanchiata. } \\
\text { Octopoda } \\
\text { Decapoda } \\
\text { Belemnitidae } \\
\text { Belopteridae } \\
\text { Belosepiidae } \\
\text { Sepiidae } \\
\text { Loliginidae }\end{array}$ \\
\hline
\end{tabular}

Table III.-ZITTEL'S Classification of Cephalopoda, 1884.

\begin{tabular}{|c|c|c|}
\hline \multicolumn{2}{|c|}{ TETRABRANCHIATA. } & DIBRANCHIATA. \\
\hline $\begin{array}{l}\text { NAUTILOIDEA. } \\
\text { Retrosiphonata } \\
\text { Orthoceratidae } \\
\text { Ascoceratidae } \\
\text { Cyrtoceratidae } \\
\text { Nautilidae } \\
\text { Trochoceratidae } \\
\text { Prosiphonata }\end{array}$ & 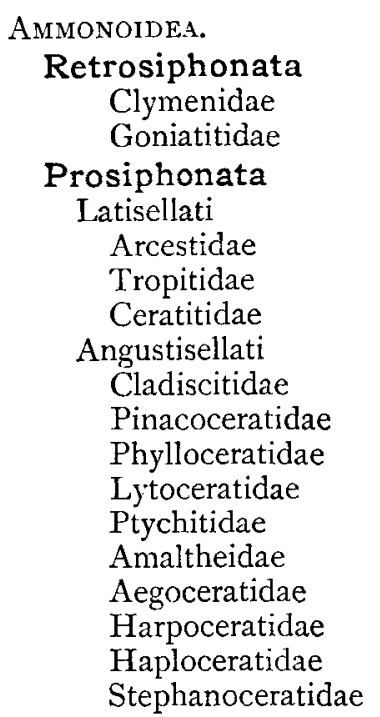 & $\begin{array}{ll}\text { DECAPODA. } & \text { OCTOPODA. } \\
\text { Phragmophora } & \\
\text { Belemnitidae } & \\
\text { Belemnoteuthidae } & \\
\text { Spirulidae } & \\
\text { Sepiophora } & \\
\text { Chondrophora } & \end{array}$ \\
\hline
\end{tabular}

TABLE IV.-BATHER'S Classification of Cephalopoda, r888.

LIPOPROTOCONCHIA. SOSIPROTOCONCHIA

NaUtiLOIDE Bactritidae
Asellate,
Latisellate, COLEOIDEA.
Osteophora $\begin{array}{ll}\text { Gomphoceratidae } & \text { Endoceratidae } \\ \text { Poterioceratidae } & \text { Actinoceratidae } \\ \text { Ascoceratidae } & \end{array}$ Cyrtoceratida Lituitidae
Trochoceratidac
Nautilidae Aulacoceratidae
Xiphoteuthidae Belemnitidae
Belopteridae Spirulidae Chondrophora Myops sid)
Beloteuthidae Teuthidae Teuthidae Loligidae
Sepiolidae Oigopsid Octopodidae
Philonexidae
Cirrhoteuthidae

TABLE V.-STEINMANN'S Classification of Cephalopoda, I8go.

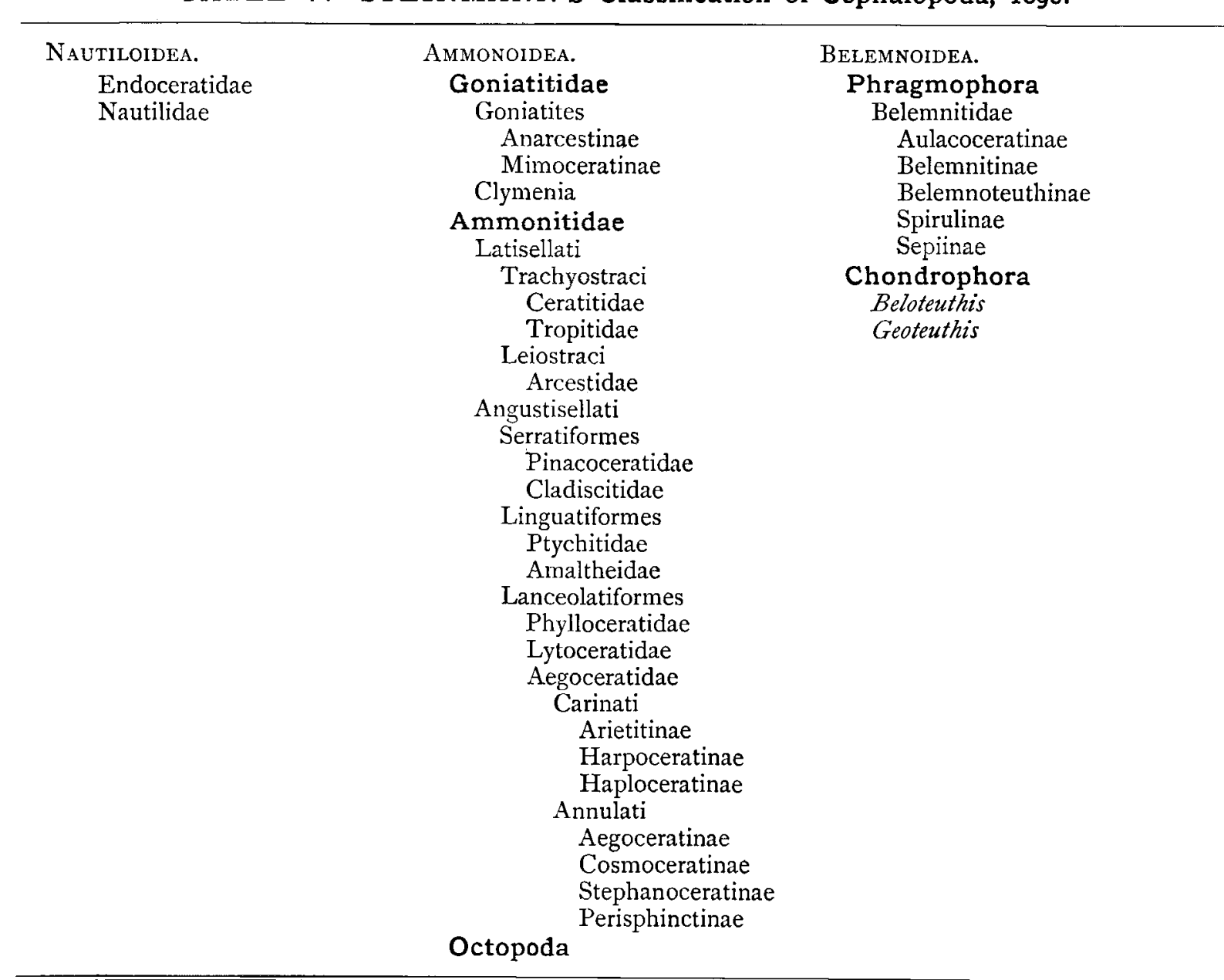


separated the initial chambers of sixty-four species of Ammonites, ascertaining their general shape and the outline of the first-formed septum. In every case the first septum is an oval, whose long axis is transverse to the plane of coiling. The variation in form consists in two elements : first the curvature of the first sutureline out of the plane of the oval; and secondly, the position of the line of greatest breadth. Whatever the later complication of the sutures may be, the first shows merely a gentle undulation. Amongst the Ammonites of the Trias the undulation sometimes starts from the extreme edge, so as to produce a single forward bend (saddle) the whole breadth of the septum. These broadsaddled forms Branco calls latisellate. Other Triassic Ammonites, and all the Jurassic and Cretaceous ones examined, have on each side of this central saddle a backward lobe, which by so much diminishes the breadth of the saddle. These Branco calls angustisellate. Of the former of these types there are two varieties : the simpler, in which the outer curve passes uniformly at the sides into the inner one; the more complicated, in which there is a small lobe at the umbilical junction. Of the latter type there are also two varieties: one in which the central saddle has converging sides, giving it a triangular shape; the other, with nearly parallel sides, making it trapezoidal. In all these the greatest transverse axis is in the centre, i.e., along the axis of revolution, and there is no constriction between the first and later chambers. The actual size of the initial chamber and its departure from the spherical shape also vary greatly, one of the largest being that of Scaphites aequalis. The distinctions thus obtained may sometimes serve to characterise genera.

Branco has also examined twenty-three Goniatites, and finds that the greater number of those in the Carboniferous are latisellate, showing two forms of saddle, the sub-triangular and the semicircular. The remainder have no undulations out of the plane of the oval, and these he calls asellate. They are separable into two types, the Ammonitiform and the Spiruliform. In the tormer, the first chamber is as involute as in the Ammonites; in general shape, however, it differs by having no maximum thickness along the central line, or by the sagittal section having sub-parallel sides, while the last half of the revolution has only the same breadth as the first half. In the latter the first chamber is a sub-spherical flask, with an oblique opening followed by a constriction, leading to a smaller-sized second chamber, thereby approximating to the first chamber in Spirula. Branco then notes that Belemnites go still further in this direction by having no obliquity in their opening. He has made no special observations of his own on the first chambers of Nautiloids, which are less necessary as these are usually unconcealed; but he expresses his opinion on the subject of the cicatrix and the supposed earlier chamber in Nautilus. The wall of the first 
chamber now seen could not, he says, have been a septum, since a septum consists of the pearly layer only, whereas, on the former, there are ornaments belonging to the outer coat. Since, moreover, the inner layer is continuous, the cicatrix is probably not a true scar, but a scar-like ornament. He notes also that B̈actrites, which is considered to be the starting point of the Ammonites, has a conical first chamber. We have already seen how Hyatt, having all this before him, still retains his views in his latest publication.

With regard to the sutures, the researches of Branco bring out a curious fact, namely that, whereas the ventral surface is always occupied by a lobe in the later sutures, the first suture, when there is any curve at all, always has a saddle; so that the septa approximate at their edges more closely here than anywhere else. If we were to argue genetically from this fact, it would certainly point to a derivation of the whole group of Ammonoidea from a Bactrites-like ancestor in which the septa bent forward on the siphonal side.

With regard to the later septa, Branco shows that when the Goniatite stage of an Ammonite is spoken of, it is not the angular sutures which are referred to, but the rounded forms, which, even in the Goniatites themselves, precede the angular ones. Nor can he find that Ammonites necessarily pass through a Ceratite stage. On the contrary, the complication is often introduced by the toothing, not of the lobes only, but of the saddles also. In detail, however, the method pursued varies greatly. The ventral lobe is always single at first, and at a later stage becomes double by the uprise of a small ventral saddle.

The surface of the septum is convex in the median line from the first in all the Ammonoids except the asellate Goniatites, in which the first few septa are concave. The siphonal funnel has been said to go forward in the Ammonites, and backward in the Goniatites; but Branco shows that the early funnels, even of the Ammonites, go backwards, and that the change is brought about, as is seen in a species of Tropites, by a partial outgrowth of the septum forwards, which gradually forms a complete ring, in which stage the funnel goes both forward and backward; then the backward part gradually dies away and only the forward is left. Hyatt regards the forward part as a distinct organ, which he distinguishes by the name of 'collar'; but he gives no proof that this view is more correct, nor does the question appear to be of much importance. No Goniatite has yet been found in which the funnel, in the latest stages, goes forwards. The varying lengths of this organ, and its apparent closure in Endoceras, may be reckoned amongst longestablished facts.

Hyatt noticed in 1872 that the siphuncle in Ammonites was much larger at first, and more or less central, or even internal in position, only taking up its position on the ventral side by degrees. 
Its early position, however, is found by Branco to have no definite relation to the Latisellate and Angustisellate groups. 'The fact of its change of position shows that we cannot always consider the siphonal to be the ventral side, as is assumed to be the case when Cyrtocerata are classified as Endo- and Exogastric, though there can be no doubt that the adult Ammonite and Spinula are coiled on different sides.

Branco could find no prosiphon in the initial chamber, as described by Munier Chalmas; but Hyatt appears now to have done so, for he gives a figure showing several plates joining the base of the siphon to the base of the bulb in Spirula, and even founds arguments upon it.

There is one other point that has been considered to have some bearing on the evolution of the Cephalopoda; namely, the distance of the septa from one another. On this subject a curious paper was published by Riefstahl ${ }^{*}$ in 1886 , in which he attempted to show that the laminæ of the Sepia shell were at first close together, and that at a later period they became separated by internal growth which took place through intussusception. Since he considered these laminæ to be the homologues of the septa of Nautilus and Ammonites, he put forward the extraordinary theory that, after these septa had first been formed at a certain distance apart, the intervening shell had grown and separated them by a further distance. Bathert soon proved that the ground-work of this argument was worthless, even in the Sepia; and it scarcely required any proof to show that the subsequent growth of the older part of the Nautilus shell was entirely imaginary. Bather, however, went somewhat further in stating that the ratio of the normal septal intervals was constant in any given shell, while the approximation of the last septa was a geratologous character. If any law could be founded on this, and applied to phylogeny, we should not find the ratio of the second chamber to the first so variable as Barrande has shown it to be; nor should we find approximate septa in the early Orthocerata, nor crowded sutures in Ammonites at their acme.

I have now passed in review most of the bases of fact which have been made out, on which schemes of classification and theories of evolution have been founded. It remains to consider the more recent of these schemes and theories.

The oldest classification with which we need deal is that of Neumayr for the Ammonites, published in 1875 , which, as it was adopted in its entirety by Wright, in his "Lias Ammonites," + is the

\footnotetext{
* "Die Sepienschale und ihre Beziehungen zu den Belemniten." Palæontographica, vol. xxxii, p. zot.

+ "The Growth of Cephalopod Shells." Geol. Mag., Dec. iii, vol iv, pp. 446-449, Oct. 1887, and "Shell-growth in Cephalopoda (Siphonopoda)," Ann. Mag. Nat. Hist., ser. 6, vol. i, pp. 298-310, April, r888.

‡ Palæontographical Soc. Monograph, ; vols, for $18_{78-1885}$.
} 
most recent detailed scheme in English literature. This divides them into four families: the Arcestida, Tropitidce, Lytoceratida, Aigoceratida, in which families are included thirty-eight genera. On this classification I need only remark that its author, were he happily still with us, would certainly regard it as quite inadequate and out of date at the present time.

The scheme which Branco has put forward as the result of his researches is also a partial one. In this, the main basis is naturally the form of the initial chamber; but other families than those above-mentioned are adopted, and it is to be noted that the Arcestidce are divided into two parts, and the Goniatitide into three. So far as it affects the Ammonites, his work has been made the basis of their classification in later and more comprehensive schemes.

For the Ammonites of the Triassic Fauna, Mojsisovics put forward another classification in his "Die Cephalapoden der Mediterranen Triasprovinz,"* in $\mathbf{1 8 8 2}$. This places in the forefront the ornaments of the shells, dividing the Ammonites into Trachyostraca, or rough-shelled, and Leiostraca, or smooth-shelled; but it is doubtful how far this is intended to be a general classification.

We must now, in point of date, come to Hyatt's scheme, which may be said to be scattered over the years between 1872 and 1883 , having to be gathered from various publications. It is not, however, complete, as he does not deal with the Dibranchiata, or with any Post-Liassic Ammonites except the Stephanocerata. The principal part of his classification may be derived from his paper of 1883 , "The Genera of Cephalopods, \&c.," which deals exclusively with Pre-Liassic forms. This mostly consists of the naming of several groups which have been made out, and of their subdivision, and gives no indication that the author had studied several larger groups, such as the Goniatites, from anything more than their published figures. The basis of his classification of the Nautiloidea is the form of the siphuncle. The development of this has, he considers, taken place by certain stages. The first is the hypothetical ancestor of the whole, where there was no siphuncle, and this he calls the Asiphonophorous stage. Next came another hypothetical type, where the siphuncle was a cæcum, i.e., was imperforate; this is the Cæcophorous stage. The first real animal met with is Macrosiphonulous, and is represented by Endoceras, the large siphuncle of which is perforated by an endosiphon, as he names it, an organ which is met with also in Actinoceras. Finally comes the Microsiphonulous stage, where the siphuncle has its ordinary form, which he regards as a degraded modification derived from the funnels, endosiphon, and endocones of Endoceras. Such, at least, is Hyatt's view in 1890 ; but it is not very clear whether he

* Abhdl, d. kk. geol. Reichsanstalt, Wien, vol. x. 
distinguishes altogether between the siphuncle and the neck of the septum. As in I883, it is by the neck that he is guided in the classification. The Holochoanoida are those in which the neck reaches from septum to septum; the Prochoanites are those in which it passes forwards; and the Metachoanites are those in which it passes backwards. The two latter names are unfortunate in that they suggest the idea of change, as though the Prochoanites had been the ancestors; but amongst the Metachoanites we find Endoceras. The Ellipochoanites are those in which the neck is too short to reach the previous septum; and amongst these the Microchoanites are those in which it is very short, as in Actinoceras, and the Macrochoanites are those in which it is fairly long, as in Bactrites alone, which form is transitional between the Nautiloids and Ammonoids. Hyatt also records in this connection some interesting details with regard to the changes in the small dorsal lobe, which he calls the annular lobe; but they do not much affect the classification.

Hyatt traces back the Arietidæ to Gymnites and Arcestes in the Trias; thence by Cyclolobus in the Permian to the Goniatitinæ. The Lytoceratidæ come from the same source by a more direct path. As for the Belemnites, he traces them, as every one does, to Aulacoceras, and considers that the flat shaped Orthoceras, called Gonioceras, which presents some peculiar structures, was the original ancestor (see Table I).

With regard to the details of Hyatt's classification, so far as they relate to the Ammonites he has studied, they appear to have some sound basis; but with respect to the others, nothing appears to me easier than to repeat the descriptions of previous authors, to give a number of names, and then to take your chance whether they are correct or not. Somewhat the same remark may be applied to the naming of the Belemnites by Bayle in 1878 .* Figures of specimens of various types, belonging to the previously established divisions, are given, and new generic names are assigned. It is the work of a nomenclaturist and not of a palæontologist.

I may next refer to the classification proposed by $F$. A. Bather in 1888 , partly in the paper above referred to on shell growth in Cephalopodat, and partly in an unpublished paper read before this Association. He puts forward more plainly than others the genetic method, and thus starts the series from a hypothetical Pre-Cambrian ancestor which he believes to have had two gills. Its shell was broadly conical, with a slight tendency to curve with a dorsal concavity, its septa were thin

* Explic. de la carte Geologique de France.

† Also in "Professor Blake and Shell-growth in Cephalopoda," Ann. Mag. Nat. Hist., ser. 6, vol. i, pp. 425-427; June, 1888 .

‡ "Pre-Canıbrian,Cephalopods : An Essay in Reconstr'zctive Palaeontology" ; Abstr. Proc. Metrop. Sci. Assoc. No. 30 . London, Dec., r888; and Netues Jahrb. f. Min., r8go, I, Referate, p. 152 
and approximate, the siphuncle was wide, entered the protoconch, secreted the septal necks, and contained some of the viscera. From such a stem arose two branches: Lipoprotoconchia, which early lost their protoconch ; and Sosiprotoconchia, which kept it. He thus puts the hypothetically lost first chamber of Nautilus in the forefront, though its existence is denied by both Barrande and Branco, who have given us almost all the data we possess. The former group constitutes the Nautiloidea, while the latter is divisible into the Ammonoidea and Coleoidea, the latter having the protoconch typically protected by secondary shell substance. The Coleoidea he divides into Osteophora and Chondrophora; the first leading through Aulacoceras and Xiphoteuthis to Belemnites and thence to Sepua --the second by Belemnoteuthis to the Teuthide (see Table IV).

The other classifications to which I may finally allude are those of the general schematists Fischer, Zittel, and Steinmann.

With regard to the first, ${ }^{*}$ which is not so full as the others, we note that the Ammonites are no longer placed with the Tetrabranchiates ; for we really know nothing positive about their gills, while the different parts of their organisation unite them more or less with both of the modern types. 'The position of the septal neck is only noted in the Tetrabranchiates, though the families included amongst the Ammonea also differ in this respect (Table II).

In Zittel's table + we still see the two main sub-divisions according to the supposed gills; while the position of the siphuncular neck is made use of in both sub-orders. Branco's division of Asellati is omitted from notice, and his other divisions are applied only to the old group of the Ammonites. In the Dibranchiates Zittel makes three divisions instead of two, considering Sepia and its allies as distinct from the rest (Table III).

There can be no doubt that Steinmann's classification, $\neq$ which is the latest in time, is the best summary of existing knowledge ; but unfortunately he seems very fond of sub-families and other divisions which do not drop very well into line. If, however, we call his smallest sub-divisions by family names, as Hyatt does, there is a considerable resemblance to the latter author's classification so far as the two are comparable. His division of the whole group into three main sub-orders, without reference to gills, is equivalent to that proposed by Bather, except that the third has the more familiar name of Belemnoidea. This name has been objected to on the ground that they have not all of them a protecting guard (belemnon); but this objection does not appear to me of much weight (Table V).

A glance at the details of these several schemes will show

* Mantiel de Conchyliologie, $1882-3$.

+ Handb. der Palzontologie, Bd. 11. $188_{4}$.

$\ddagger$ Steinmann und Doederlein, Elemente der Palaontologie, II Hälíte, Leipzig, IBgo. 
at once in what a transition state the subject lies at present. Some few of the greater features are beginning to be clear by their being common to the several arrangements; but the location of various families and genera, and the value that is to be assigned to the various points of difference seem still quite undecided. From what I have already said, however, it will be scen that I think the field has now been opened for a new method of investigation in which 'genera' and 'species' will be done away with as palæontological terms, while 'lineage' and 'mutations,' or something equivalent to these, will take their place. The result must necessarily be a great alteration in the scheme of classification. Tribes, families, races, and all that is connected with genealogy, will remain; but classes and orders which separate contemporaneous beings will be out of date. None, therefore, of the above classifications are likely to last long, though each in its way contains many elements of truth.

I have confined myself in this address to a statement of what has been arrived at by others, with merely passing criticism. If I am spared to address you another year, I shall hope to give you some of my own ideas upon the subject.

\section{ON GEOLOGICAL ZONES.}

By HORACE B. WOODWARD, F.G.S.

[Read Friday, March 4 th, 1892.]

THE subject of Zones is one which concerns all geologists, whether their particular studies are
the field, to fossils, or to eruptive rocks.

Although geology has been defined, and by a President of the British Association, * as a "heterogeneous compound of sciences," yet its aims are systematic, and one of the more important of these is the determination of the order of succession of life on the earth. This subject is necessarily based on the work of the fieldgeologist, who determines the sequence of the rocks in a certain area; but the aid of the palæontologist is needed to establish the correlation of the strata in areas apart, and to picture the conditions which attended their deposition. From the study of local successions of strata and their fossil contents, we are led to consider the great epochs in the life history of the earth, and thus we come face to face with the somewhat vexed subject of geological chronology. In this subject even the petrologist, who may be considered a sort of lifeless geologist, manifests interest, for he is concerned with the sequence of volcanic phenomena.

Since the days when William Smith showed that our British formations were characterised by different assemblages of fossils,

$$
\text { APRIL, I 892.] Address, Brit. Assoc., I889. }
$$

